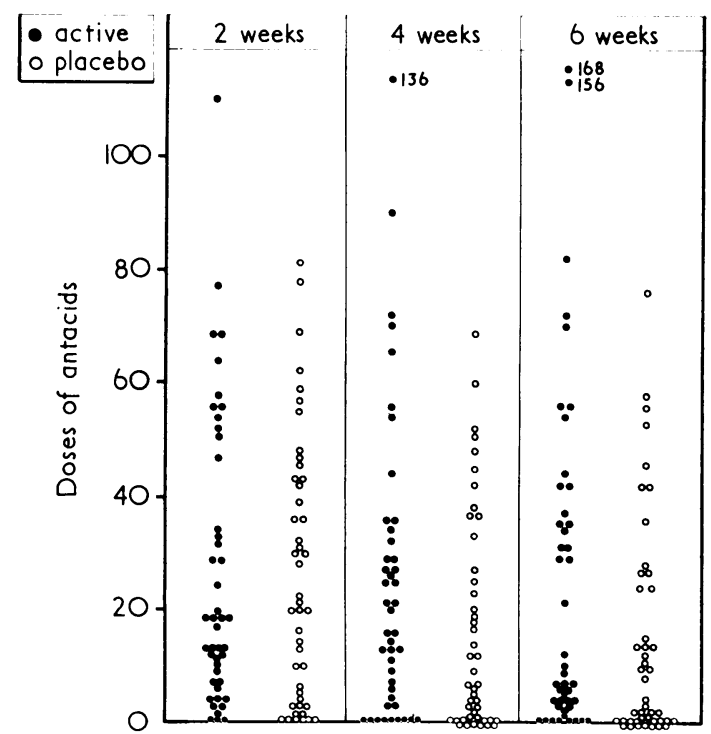

FIG. 4-Number of doses of antacid consumed by each patient during each fortnight of the trial.

probably document the natural evolution of an attack of duodenal ulcer under outpatient management.

The present data are in agreement with those of Feldman and Gilat (1971), but do not confirm the beneficial effect on symptoms of duodenal ulcer reported by others on the basis of controlled observations on a total of 70 patients treated for two or four weeks (Tewari and Trembalowicz, 1968; Mills and Mamrau, 1969). The dose used by these workers was the same as in the present series, but a commercially available tablet (Caved-S) was prescribed which, in addition to $380 \mathrm{mg}$ of glycyrrhizinic-acid-reduced liquorice, contained bismuth subnitrate $100 \mathrm{mg}$, colloidal aluminium hydroxide $100 \mathrm{mg}$, mag- nesium carbonate $200 \mathrm{mg}$, sodium bicarbonate $100 \mathrm{mg}$, and frangula $30 \mathrm{mg}$. It is possible, though unlikely, that the small quantity of antacid and laxative contained in the commercial tablet or its physical properties are responsible for the difference in the respective results. If the peak acidity in gastric juice of men with duodenal ulcer is taken to be $125 \mathrm{mEq} / 1$. (Baron, 1963), in-vitro tests have shown that two tablets of the commercial preparation would raise the $\mathrm{pH}$ of $45 \mathrm{ml}$ of gastric juice to $3 \cdot 0$, which would account for about seven minutes of secretion at the peak histamine-stimulated rate. Moreover our patients were encouraged to consume sufficient alkali to relieve their symptoms. In other trials the rate of healing of gastric ulcers was significantly accelerated by capsules of glycyrrhizinicacid-reduced liquorice without alkali or frangula, similar to those used in the present investigation (Turpie et al., 1969).

It is, however, generally accepted that in the absence of unequivocal radiological criteria the assessment of results of treatment in duodenal ulcer is difficult, based as it is on subjective variables such as pain or on indirect measures such as quantity of alkali consumed. Further clinical trials are needed if the usefulness of glycyrrhizinic-acid-reduced liquorice for the treatment of duodenal ulcer is to be established.

We are grateful to Mr. R. W. Richardson, department of biochemistry, Coventry and Warwickshire Hospital, Coventry, for the pepsinogen estimations, to the Hospital Pharmacists for their help, and to departments of medical illustration and photography, Central Middlesex Hospital, for the figures.

\section{References}

Baron, J. H. (1963). Gut, 4, 243.

Feldman, H., and Gilat, T. (1971). Gut, 12, 449

Mills, D. H., and Damrau, F. (1969). International Medical Digest, 4, 36.

Russell, R. I., and Dickie, J. E. N. (1968). Fournal of Therapeutic and Clinical Research, 2, 2 .

Tewari, S. N., and Trembalowicz, F. C. (1968). Gut, 9, 48.

Turpie, A. G. G., Runcie, J., and Thompson, T. J. (1969). Gut, 10, 299.

\title{
Effects of Externally Applied Pressure on the Haemodynamics of the Lower Limb
}

\author{
S. SABRI, V. C. ROBERTS, L. T. COTTON
}

British Medical fournal, 1971, 3, 503-508

\section{Summary}

The effects of externally applied pressure of 5-150 $\mathrm{mm} \mathrm{Hg}$ on the haemodynamics of the leg of dog and man were investigated. The criteria used for the assessments included femoral arterial and venous blood flow as well as vascular hydraulic conductance. The results indicated that external pressure of $5 \mathrm{~mm} \mathrm{Hg}$ results in a very small non-significant increase in the femoral arterial and venous flow. Higher external pressure of $15 \mathrm{~mm} \mathrm{Hg}$ or more significantly reduces the femoral arterial and

\footnotetext{
Department of Biomedical Engineering, King's College Hospital Medical School, London S.E.5

S. SABRI, M.B., PH.D., Honorary Senior Surgical Registrar/Lecturer V. C. ROBERTS, M.SC., PH.D., Honorary Lecturer

L. T. COTTON, M.CH., F.R.C.S., Consultant Surgeon and Director of Department.
}

venous flows as well as the vascular conductance. It therefore seems that compression produced by bandaging in horizontal supine subjects has little or no haemodynamic value and may prove to be harmful unless carefully controlled.

\section{Introduction}

Venous stasis in the lower limb of resting recumbent patients (McLachlin et al., 1960) is probably an important cause of thrombosis in the deep veins of the calf (Hadfield, 1950). Radiographic and anatomical studies have shown that venous blood stagnates in the thin-walled soleal sinuses, which may have a diameter of up to $1 \mathrm{~cm}$ (Gibbs, 1957) and a length of up to $5 \mathrm{~cm}$ (Cotton and Clark, 1965). Induction of anaesthesia and associated inactivity of the calf muscles remarkably aggravates the stagnation in these sinuses (Cotton and Clark, 1965; Clark and Cotton, 1968).

Compression of the lower limb to prevent venous stasis and subsequent venous thrombosis was first suggested by Piere 
Dionis in the sixteenth century (Foote, 1960). Compression of the leg by inflatable G-suit leggings (Stanton et al., 1949) or by elastic stockings (Osborn and Wright, 1949; Meyrowitz and Crook, 1960; Meyrowiz and Nelson, 1964; Makin et al., 1969) produced a significant reduction in the foot-to-groin transit time of intravenously injected substances. It is not known, however, if external compression of the leg will prevent the peroperative venous stasis, which may contribute to the formation of thrombi while the operation is still in progress (Flanc et al., 1968).

The criginal investigation into the effects of the application of external pressure was recently reported by this department (Spiro et al., 1970; Robert, 1971). Since that date we have developed an instrument for continuously monitoring the peripheral vascular conductance (Roberts et al., 1971). With this we have been able to extend the original investigation to produce a more complete haemodynamic analysis of the effects of external pressure on flow in the lower limb. The criteria studied in this current investigation are (1) femoral vein flow, (2) femoral artery flow, and (3) peripheral vascular conductance.

This investigation has been conducted (1) to determine the effects of varying degrees of external compression of the leg on femoral venous flow, (2) to assess the effects of a 30-minute period of sustained compression of the limb on femoral venous flow, and (3) to evaluate the effects of external compression on the perfusion of the limb.

\section{Material and Method}

\section{ANIMAL EXPERIMENTS}

Eight greyhound dogs weighing 22-31 kg were anaesthetized with intravenous pentobarbitone sodium in a dose of $30 \mathrm{mg} / \mathrm{kg}$ and maintained with supplementary doses as required. The femoral arteries and veins of both sides were exposed and all tributaries of the femoral veins were ligated. External pressure was applied to one limb by means of a standard half leg inflatable plastic splint (Parke, Davis \& Co.) while the other limb acted as control.

The dogs were divided into two groups. The first group was used to investigate the effects of graded incremental external pressure on the femoral venous flow and pressure. The femoral venous pressure was measured by passing a Portex 12-in $(30-\mathrm{cm})$ (red) intravenous catheter retrogradely via a deep tributary into the common femoral vein. The tip of the intravenous catheter was placed well beneath the compressing splint. The femoral venous pressure line was connected to a Bell and Howell pressure transducer type L221 and recorded on a Devices M4 recorder. The splint was inflated to pressures of $5,10,15,20,40,60,80,100,120$, and $140 \mathrm{~mm} \mathrm{Hg}$. Each pressure was maintained for five minutes followed by a rest period of five minutes. Blood flow was measured with a Nycotron electromagnetic blood flowmeter type 372, using cuff probes (acute probes type PS). To ensure baseline stability the flowmeter was allowed to warm up for a period of half an hour before use. Continuous recordings of blood flow were traced by an ultraviolet recorder, and the mean flows were obtained from the traces by planimetry.

The second group of dogs was used to investigate the effects of graded external pressure on the arterial flow and vascular hydraulic conductance (which is the reciprocal of peripheral resistance) of the lower limb. The femoral vessels of both groins were exposed, and all their branches and tributaries were divided and ligated. On the right leg the profunda artery was preserved and cannulated for pressure measurements with a Portex 12-in $(30-\mathrm{cm})$ (red) intravascular catheter. This investigation was divided into two parts.

In the first part the effects of external application of pressures of $5,10,20,40,60$, and $80 \mathrm{~mm} \mathrm{Hg}$ on femoral arterial flow was measured in both sides. In each case a three-minute period of compression was followed by a recovery period of three minutes. Simultaneous recordings of arterial flow, pressure, and vascular conductance were made on the ultraviolet recorder, from which the mean values were subsequently obtained by planimetry. The vascular conductance was measured by an analogue computing unit which instantaneously divided the mean pressure by the mean flow and indicated the state of arterial perfusion of the limb (Roberts et al., 1971).

In the second part the effects of sustained application of external pressure of $5 \mathrm{~mm} \mathrm{Hg}$ on femoral venous blood flow was followed for a period of 30 minutes. The flow probes were placed on the common femoral veins of both sides and an external pressure of $5 \mathrm{~mm} \mathrm{Hg}$ was applied to the right leg for a period of 30 minutes, while the left leg acted as control. The readings of venous flows were taken from the ultraviolet recorder trace at five-minute intervals.

\section{PATIENT INVESTIGATIONS}

Nine patients undergoing surgery for bilateral varicose veins were asked for their co-operation and informed consent. General anaesthesia was induced and maintained with spontaneous respiration, since venous flows can be grossly affected with intermittent positive-pressure respiration (Dyde and Bethal, 1968). Both femoral veins were exposed through transverse incisions in the groins. The position of the flow probe on the common femoral vein was very close to the saphenofemoral junction. Therefore, in order to ensure axisymmetric flow in the femoral vein, the saphenofemoral junction was divided before any measurements were made. Previously calibrated cuff flow probes were then fitted round the femoral veins. The right lower limb was placed in an inflatable splint and the left lower limb was used as a control. The procedure was basically similar to that of the animal experiments, except that shorter periods of compression and rest were used. This modification had to be made to avoid prolonging the operative time. Each period of compression and each period of rest lasted only until a steady state had been achieved and maintained for one minute. In two patients, however (Subjects 3 and 7), the compression period was sustained for four minutes in order to confirm that the increased flow was maintained.

The effect of compression on femoral venous pressure was not investigated in order to avoid any possible damage of the common femoral vein. Splint pressures were also restricted to pressures of $5,10,15,20,30$, and $40 \mathrm{~mm} \mathrm{Hg}$. No vascular conductance measurements were made on these patients. Three patients were investigated with both a below-knee splint and a full-length leg and thigh splint. In another three patients only the below-knee splint was used. In the final three patients only the full-length splint was used. Thus six sets of data were provided for each type of splint. No control flow measurement was possible in two patients because of probe failure in Subject 4 and unilateral varicosities in Subject 1.

\section{Results}

The effects of various splint pressures on femoral venous blood flow $\left(\dot{Q}_{v}\right)$ and venous pressure in the segment of femoral vein which lay beneath the splint $\left(P_{v}\right)$ are shown in Table $I$. The results obtained from Table $I$ are plotted in Fig. 1, which shows clearly that splint pressure exceeding $12 \mathrm{~mm} \mathrm{Hg}$ produces a progressive decrease in femoral venous flow. The maximal decrease in venous flow was $60 \%$ at a splint pressure of $100 \mathrm{~mm}$ $\mathrm{Hg}$. Further increase in the splint pressure did not result in any further diminution of the femoral venous flow. The maximum venous flow was obtained at a splint pressure of $10 \mathrm{~mm} \mathrm{Hg}$.

The effects of splint pressures of $5,10,15,20,30,40,60$, and $80 \mathrm{~mm} \mathrm{Hg}$ on the mean femoral arterial flow in both the 
TABLE I-Effect of Splint Pressure on Femoral Venous Flow

\begin{tabular}{|c|c|c|c|c|c|c|}
\hline \multirow{2}{*}{$\begin{array}{c}\text { Splint } \\
\text { Pressure } \\
\text { (mm Hg) }\end{array}$} & \multicolumn{2}{|c|}{ Dog 1} & \multicolumn{2}{|c|}{ Dog 2} & \multicolumn{2}{|c|}{$\operatorname{Dog} 3$} \\
\hline & $\underset{(\mathrm{ml} / \mathrm{min})}{\dot{\mathrm{Q}} \mathrm{v}}$ & $\underset{(\mathrm{mm}}{\stackrel{P}{\mathrm{Pv}})}$ & $\underset{(\mathrm{ml} / \mathrm{min})}{\dot{\mathrm{Q}} \mathrm{v}}$ & $\underset{(\mathrm{mm} \mathbf{H g})}{\mathrm{Pv}_{\mathbf{v}}}$ & $\underset{(\mathrm{ml} / \mathrm{min})}{\dot{\mathrm{Q}} \mathrm{v}}$ & $\underset{(\mathrm{mm}}{\left.\mathrm{Pv}_{\mathrm{Hg}}\right)}$ \\
\hline 0 & - & - & 153 & $3 \cdot 0$ & 188 & $12 \cdot 0$ \\
\hline 5 & - & - & 148 & 5.0 & 193 & 13.0 \\
\hline 0 & 268 & 10.5 & 138 & 3.5 & 168 & 8.0 \\
\hline 10 & 228 & 13.7 & 136 & 6.5 & 187 & $17 \cdot 0$ \\
\hline 0 & 243 & 10.5 & 136 & 3.5 & 189 & 10.0 \\
\hline 15 & 224 & 18.5 & 129 & 10.0 & 168 & $24 \cdot 0$ \\
\hline 0 & 290 & 10.5 & 140 & 3.5 & 173 & 9.0 \\
\hline 20 & 235 & 13.0 & 131 & $12 \cdot 0$ & 154 & $34 \cdot 0$ \\
\hline 0 & 259 & 10.5 & 152 & 3.0 & 190 & 9.0 \\
\hline 40 & 132 & 43.0 & 106 & $26 \cdot 0$ & 136 & $42 \cdot 0$ \\
\hline 0 & 278 & $10 \cdot 0$ & 170 & 3.0 & 177 & 16.0 \\
\hline 60 & 95 & 58.0 & 100 & $40 \cdot 0$ & 105 & 36.0 \\
\hline 0 & 269 & 10.5 & 206 & 3.0 & 159 & - \\
\hline 80 & 73 & 62.0 & 102 & 56.0 & 85 & 二 \\
\hline 0 & 243 & 10.5 & 186 & 3.0 & 163 & $15 \cdot 0$ \\
\hline 100 & 43 & 58.0 & 92 & $72 \cdot 0$ & 77 & 03.0 \\
\hline 0 & 240 & $10 \cdot 0$ & 200 & - & 166 & - \\
\hline 120 & 54 & 45.0 & 96 & $80 \cdot 0$ & 75 & - \\
\hline 0 & 264 & $10 \cdot 0$ & 221 & $2 \cdot 0$ & 174 & - \\
\hline 140 & 72 & 37.5 & 100 & $90 \cdot 0$ & 76 & - \\
\hline
\end{tabular}

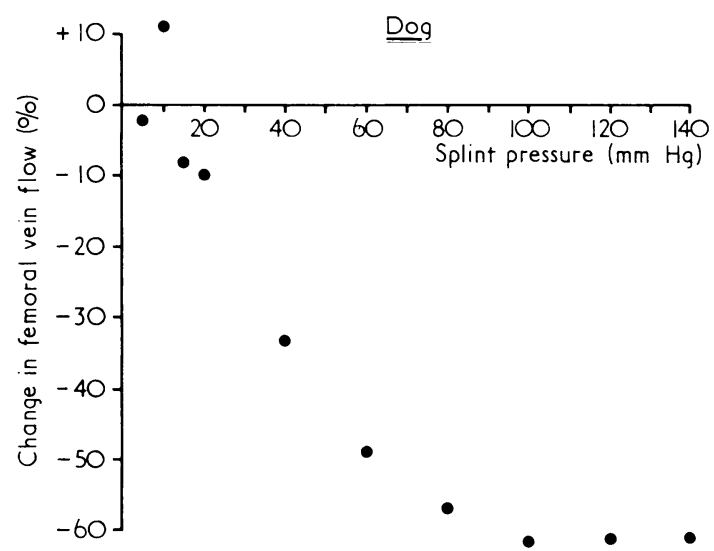

FIG. 1-Effect of various splint pressures (mm $\mathrm{Hg}$ ) on percentage change in femoral venous flow in the dog.

experimental limb $\left(\dot{\mathrm{Q}}_{\mathrm{e}}\right)$ and the control $\operatorname{limb}\left(\dot{\mathrm{Q}}_{\mathrm{c}}\right)$ are shown in Table II. Also the effects of these various pressures on the vascular hydraulic conductance $\left(G_{v}\right) \mathrm{ml} / \mathrm{min} / \mathrm{mm} \mathrm{Hg}$ in the experimental limb. The vascular conductance was not measured in one experiment because of instrument failure. The results from Table II are plotted as Figs. 2 and 3. Fig. 2 shows the percentage change in femoral arterial flow as a function of the splint pressure. Each point represents the mean value of four readings. Splint pressure of $5 \mathrm{~mm} \mathrm{Hg}$ produced an increase in the femoral arterial blood flow of about $9 \%$. Thereafter there is a progressive reduction in arterial blood flow as the splint pressure

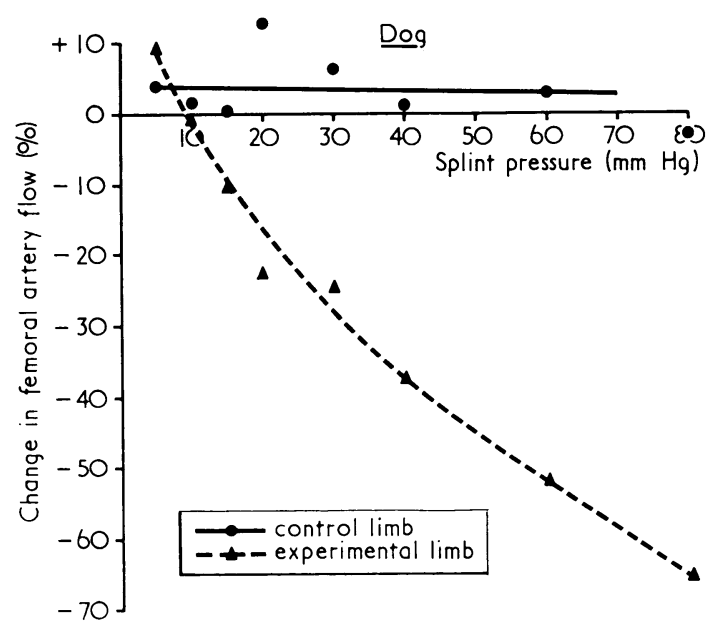

FIG. 2-Effect of various splint pressures $(\mathrm{mm} \mathrm{Hg}$ ) on the percentage change in femoral arterial flow in the dog.

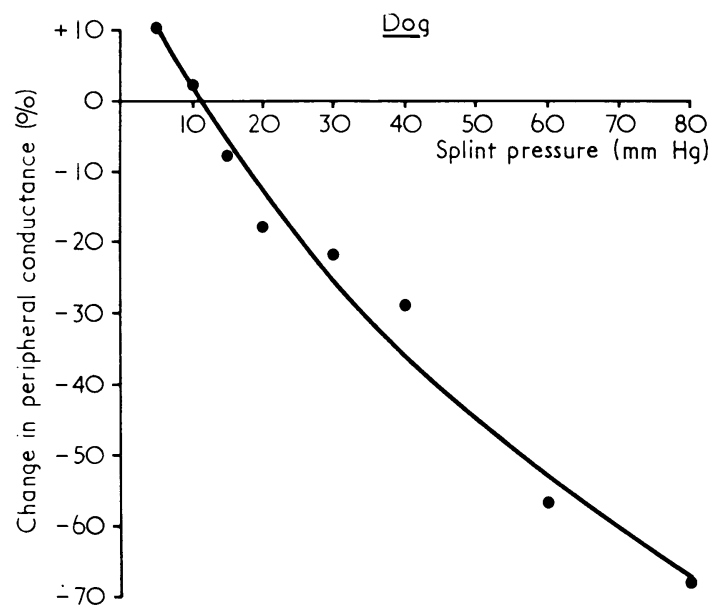

FIG. 3-Effects of compression of the lower limb on the vascular hydraulic conductance of the experimental limb in the dog.

increases. The flow in the control limb shows a small but haphazard rise and is probably not significant. Fig. 3 shows the effects of compression of the limb on the vascular hydraulic conductance of the experimental limb. It can be seen from Figs. 2 and 3 that compression of the limb has a similar effect on both the vascular conductance and the femoral arterial flow.

TABLE II-Effect of Splint Pressure on Femoral Artery Flow and on Vascular Hydraulic Conductance $\left(G_{\mathrm{V}}\right)$

\begin{tabular}{|c|c|c|c|c|c|c|c|c|c|c|c|c|}
\hline \multirow{2}{*}{$\begin{array}{c}\text { Splint } \\
\text { Pressure } \\
(\mathrm{mm} \mathrm{Hg})\end{array}$} & \multicolumn{3}{|c|}{$\operatorname{Dog} 5$} & \multicolumn{3}{|c|}{$\operatorname{Dog} 6$} & \multicolumn{3}{|c|}{$\operatorname{Dog} 7$} & \multicolumn{3}{|c|}{$\operatorname{Dog} 8$} \\
\hline & $\begin{array}{c}\dot{\mathrm{Q}}_{\mathrm{c}} \\
(\mathrm{ml} / \mathrm{min})\end{array}$ & $\begin{array}{c}\dot{\mathrm{Q}}_{\mathrm{e}} \\
(\mathrm{ml} / \mathrm{min})\end{array}$ & $\begin{array}{c}\mathrm{Gv}_{\mathrm{v}} \\
(\mathrm{ml} / \mathrm{min} / \\
\mathrm{mm} \mathrm{Hg})\end{array}$ & $\begin{array}{c}\dot{\mathrm{Q}}_{\mathrm{c}} \\
(\mathrm{ml} / \mathrm{min})\end{array}$ & $\begin{array}{c}\dot{\mathrm{Q}} \mathrm{e} \\
(\mathrm{ml} / \mathrm{min})\end{array}$ & $\begin{array}{c}\mathrm{Gv}_{\mathrm{v}} \\
(\mathrm{ml} / \mathrm{min} / \\
\mathrm{mm} \mathrm{Hg})\end{array}$ & $\begin{array}{c}\dot{\mathrm{Q}}_{\mathrm{c}} \\
(\mathrm{ml} / \mathrm{min})\end{array}$ & $\begin{array}{c}\dot{\mathrm{Q}}_{\mathrm{e}} \\
(\mathrm{ml} / \mathrm{min})\end{array}$ & $\begin{array}{c}\mathrm{Gv}_{\mathrm{v}} \\
(\mathrm{ml} / \mathrm{min} / \\
\mathrm{mm} \mathrm{Hg})\end{array}$ & $\begin{array}{c}\dot{\mathrm{Q}} \mathrm{c} \\
(\mathrm{ml} / \mathrm{min})\end{array}$ & $\begin{array}{c}\dot{\mathrm{Q} e} \\
(\mathrm{ml} / \mathrm{min})\end{array}$ & $\begin{array}{c}\mathrm{Gv} \\
(\mathrm{ml} / \mathrm{min} / \\
\mathrm{mm} \mathrm{Hg})\end{array}$ \\
\hline $\begin{array}{r}0 \\
5 \\
0 \\
10 \\
0 \\
15 \\
0 \\
20 \\
0 \\
30 \\
0 \\
40 \\
0 \\
60 \\
0 \\
80\end{array}$ & $\begin{array}{r}140 \\
164 \\
132 \\
148 \\
120 \\
140 \\
112 \\
160 \\
104 \\
140 \\
124 \\
128 \\
128 \\
68 \\
108 \\
80\end{array}$ & $\begin{array}{r}116 \\
136 \\
118 \\
140 \\
108 \\
114 \\
120 \\
108 \\
106 \\
96 \\
106 \\
88 \\
96 \\
52 \\
84 \\
36\end{array}$ & $\begin{array}{l}0.76 \\
0.92 \\
0.78 \\
0.93 \\
0.70 \\
0.75 \\
0.79 \\
0.71 \\
0.70 \\
0.66 \\
0.70 \\
0.57 \\
0.65 \\
0.30 \\
0.56 \\
0.18\end{array}$ & $\begin{array}{l}280 \\
272 \\
280 \\
304 \\
264 \\
248 \\
272 \\
280 \\
268 \\
232 \\
238 \\
272 \\
160 \\
224 \\
200 \\
224\end{array}$ & $\begin{array}{r}232 \\
228 \\
260 \\
224 \\
234 \\
184 \\
196 \\
120 \\
208 \\
122 \\
208 \\
82 \\
180 \\
76 \\
156 \\
8\end{array}$ & $\begin{array}{l}= \\
= \\
= \\
= \\
= \\
= \\
= \\
=\end{array}$ & $\begin{array}{l}76 \\
76 \\
72 \\
72 \\
72 \\
72 \\
72 \\
72 \\
72 \\
72 \\
72 \\
76 \\
72 \\
72 \\
76 \\
76\end{array}$ & $\begin{array}{r}82 \\
86 \\
80 \\
72 \\
82 \\
64 \\
78 \\
52 \\
84 \\
48 \\
100 \\
48 \\
110 \\
28 \\
101 \\
40\end{array}$ & $\begin{array}{l}0.58 \\
0.61 \\
0.56 \\
0.50 \\
0.58 \\
0.42 \\
0.55 \\
0.34 \\
0.60 \\
0.30 \\
0.62 \\
0.32 \\
0.78 \\
0.12 \\
0.70 \\
0.14\end{array}$ & $\begin{array}{l}176 \\
175 \\
157 \\
131 \\
124 \\
113 \\
108 \\
114 \\
107 \\
110 \\
151 \\
121 \\
112 \\
130 \\
107 \\
108\end{array}$ & $\begin{array}{r}134 \\
149 \\
127 \\
131 \\
120 \\
116 \\
107 \\
111 \\
102 \\
98 \\
120 \\
96 \\
111 \\
79 \\
99 \\
54\end{array}$ & $\begin{array}{l}0.85 \\
0.89 \\
0.86 \\
0.83 \\
0.80 \\
0.79 \\
0.77 \\
0.73 \\
0.73 \\
0.65 \\
0.79 \\
0.63 \\
0.73 \\
0.50 \\
0.71 \\
0.32\end{array}$ \\
\hline
\end{tabular}


The effects of sustained application of external pressure of $5 \mathrm{~mm} \mathrm{Hg}$ on the femoral venous flow in both the experimental $\operatorname{limb}\left(\dot{Q}_{\mathrm{e}}\right)$ and the control limb $\left(\dot{\mathrm{Q}}_{\mathrm{c}}\right)$ are summarized in Table III. The net change in flow ( $\Delta \dot{\mathrm{Q}}$ net) was calculated by subtraction of the change in flow in the control limb $\left(\Delta \dot{\mathrm{Q}}_{\mathrm{c}}\right)$ from the change in the experimental limb $\left(\Delta \dot{\mathbf{Q}}_{\mathrm{e}}\right)$. The results of the percentage change in venous flow obtained with a sustained external pressure of $5 \mathrm{~mm} \mathrm{Hg}$ obtained from Table III are plotted in Fig. 4. This shows that $5 \mathrm{~mm} \mathrm{Hg}$ produces an initial increase in venous flow which gradually diminished over a period of 15-20 minutes.

TABLE III-Effect of Sustained External Pressure on Femoral Venous Flow (Vein Flows, $5 \mathrm{~mm} \mathrm{Hg}$ Pressure)

\begin{tabular}{|c|c|c|c|c|c|}
\hline $\begin{array}{l}\text { Duration of } \\
\text { Pressure } \\
\text { Application } \\
\text { (min) }\end{array}$ & $\underset{(\mathrm{ml} / \mathrm{min})}{\dot{\mathrm{Q}}_{\mathrm{c}}}$ & $\underset{(\mathrm{ml} / \mathrm{min})}{\dot{\mathrm{Q}}_{\mathbf{e}}}$ & $\frac{\Delta \dot{Q}_{c}}{(\%)}$ & $\begin{array}{l}\Delta \dot{\mathrm{Q}}_{\mathrm{e}} \\
(\%)\end{array}$ & $\begin{array}{c}\Delta \dot{Q}_{\text {net }} \\
(\%)\end{array}$ \\
\hline $\begin{array}{r}0 \\
5 \\
10 \\
15 \\
20 \\
25 \\
30\end{array}$ & $\begin{array}{l}200 \\
184 \\
184 \\
184 \\
176 \\
176 \\
184\end{array}$ & $\begin{array}{l}224 \\
228 \\
256 \\
256 \\
240 \\
240 \\
240\end{array}$ & $\begin{array}{r}-8 \cdot 0 \\
-8.0 \\
-8 \cdot 0 \\
-12 \cdot 0 \\
-12 \cdot 0 \\
-8.0\end{array}$ & $\begin{array}{r}-\overline{+1.8} \\
+14.3 \\
+14.3 \\
+7.1 \\
+7.1 \\
+7.1\end{array}$ & $\begin{array}{r}\overline{+9} \cdot 8 \\
+22.3 \\
+22.3 \\
+19 \cdot 1 \\
+19.1 \\
+15.1\end{array}$ \\
\hline
\end{tabular}

\section{PATIENT INVESTIGATIONS}

The patient investigations yielded results which were comparable with those obtained in the animal experiments. Tables IV and V show the effects of compression on femoral venous flow using the below-knee splint and full-length splint respectively. The splint pressures investigated were $5,10,1, \bar{p}, 20$, and $40 \mathrm{~mm} \mathrm{Hg}$.

The results obtained from Tables IV and V are plotted in Figs. 5 and 6 respectively. Fig. 5 shows the effects of compression of the leg on venous flows in both the control limb $\left(\dot{Q}_{c}\right)$ and experimental $\operatorname{limb}\left(\dot{Q}_{\mathrm{e}}\right)$ of the below-knee splint, while Fig. 6 shows the effects of the full-length splint. It is quite clear that the full-length splint inflated to a pressure of $5 \mathrm{~mm} \mathrm{Hg}$ produces an increase of the femoral venous flow of $15 \%$.

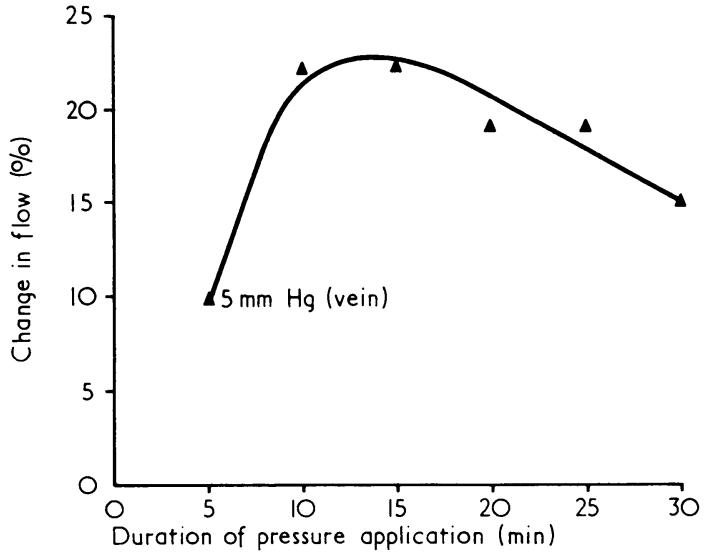

FIG. 4-Effect of sustained application of external pressure of $5 \mathrm{~mm} \mathrm{Hg}$ for a period of 30 minutes on femoral venous blood flow.

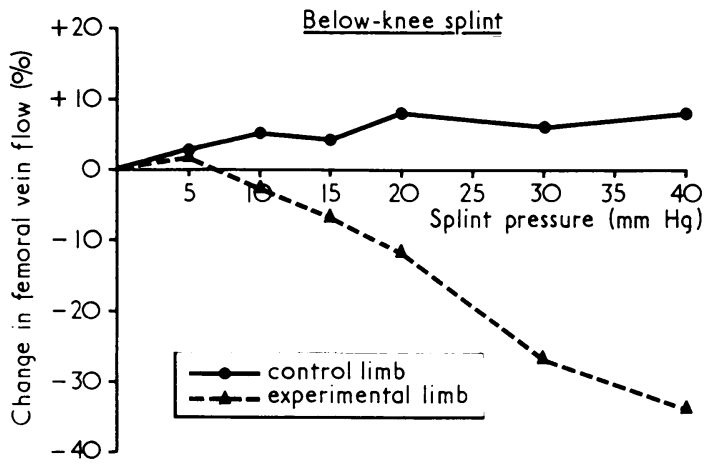

FIG. 5-Changes in human femoral venous blood flow produced by varying splint pressures for below-knee splint.

TABLE IV-Effect of Compression on Femoral Venous Flow with Below-knee Splint

\begin{tabular}{|c|c|c|c|c|c|c|c|c|c|c|c|c|}
\hline \multirow{2}{*}{$\begin{array}{l}\text { Splint Pressure } \\
\text { (mm Hg) }\end{array}$} & \multicolumn{2}{|c|}{ Subject 1} & \multicolumn{2}{|c|}{ Subject 2} & \multicolumn{2}{|c|}{ Subject 3} & \multicolumn{2}{|c|}{ Subject 4} & \multicolumn{2}{|c|}{ Subject 5} & \multicolumn{2}{|c|}{ Subject 6} \\
\hline & $\dot{Q}_{c}$ & $\dot{Q}_{e}$ & $\dot{Q}_{c}$ & $\dot{Q}_{e}$ & $\dot{Q}_{c}$ & $\dot{Q}_{e}$ & $\overline{\mathbf{Q}_{c}}$ & $\dot{Q}_{e}$ & $\dot{Q}_{c}$ & $\dot{Q}_{e}$ & $\dot{Q}_{c}$ & $\dot{Q}_{e}$ \\
\hline $\begin{array}{r}0 \\
5 \\
0 \\
10 \\
0 \\
15 \\
0 \\
20 \\
0 \\
30 \\
0 \\
40\end{array}$ & $\begin{array}{l}= \\
= \\
= \\
= \\
=\end{array}$ & $\begin{array}{l}- \\
349 \\
360 \\
356 \\
367 \\
358 \\
328 \\
\overline{-} \\
367 \\
285\end{array}$ & $\begin{array}{l}164 \\
172 \\
164 \\
172 \\
164 \\
176 \\
164 \\
172 \\
168 \\
174 \\
164 \\
168\end{array}$ & $\begin{array}{l}196 \\
216 \\
200 \\
208 \\
194 \\
212 \\
204 \\
202 \\
212 \\
200 \\
208 \\
180\end{array}$ & $\begin{array}{l}\bar{Z} \\
258 \\
252 \\
\bar{Z} \\
\bar{Z} \\
228 \\
249 \\
246\end{array}$ & $\begin{array}{l}\overline{ } \\
294 \\
308 \\
\overline{-} \\
\overline{-} \\
302 \\
262 \\
297 \\
240\end{array}$ & $\begin{array}{l}340 \\
340 \\
344 \\
344 \\
324 \\
324 \\
296 \\
300 \\
268 \\
292 \\
260 \\
276\end{array}$ & $\begin{array}{l}284 \\
284 \\
284 \\
274 \\
262 \\
238 \\
264 \\
214 \\
260 \\
176 \\
260 \\
164\end{array}$ & $\begin{array}{l}480 \\
492 \\
444 \\
444 \\
420 \\
444 \\
396 \\
444 \\
420 \\
456 \\
402 \\
480\end{array}$ & $\begin{array}{l}324 \\
328 \\
300 \\
280 \\
296 \\
268 \\
268 \\
232 \\
280 \\
210 \\
264 \\
188\end{array}$ & $\begin{array}{l}90 \\
90 \\
74 \\
84 \\
84 \\
86 \\
80 \\
90 \\
90 \\
92 \\
80 \\
84\end{array}$ & $\begin{array}{r}98 \\
92 \\
100 \\
98 \\
104 \\
86 \\
98 \\
76 \\
106 \\
66 \\
88 \\
52\end{array}$ \\
\hline
\end{tabular}

TABLE v-Effect of Compression on Femoral Venous Flow with Full-length Splint

\begin{tabular}{|c|c|c|c|c|c|c|c|c|c|c|c|c|}
\hline \multirow{2}{*}{$\begin{array}{l}\text { Splint Pressure } \\
\text { (mm Hg) }\end{array}$} & \multicolumn{2}{|c|}{ Subject 7} & \multicolumn{2}{|c|}{ Subject 8} & \multicolumn{2}{|c|}{ Subject 4} & \multicolumn{2}{|c|}{ Subject 2} & \multicolumn{2}{|c|}{ Subject 5} & \multicolumn{2}{|c|}{ Subject 9} \\
\hline & $\dot{Q}_{c}$ & $\dot{Q}_{e}$ & $\dot{\mathbf{Q}}_{\mathrm{c}}$ & $\dot{Q}_{e}$ & $\dot{Q}_{c}$ & $\dot{\mathbf{Q}}_{\mathbf{e}}$ & $\dot{Q}_{c}$ & $\dot{Q}_{e}$ & $\dot{\mathbf{Q}}_{\mathrm{c}}$ & $\dot{Q}_{e}$ & $\dot{Q}_{c}$ & $\dot{\mathbf{Q}}_{\mathrm{e}}$ \\
\hline $\begin{array}{r}0 \\
5 \\
0 \\
10 \\
0 \\
15 \\
0 \\
20 \\
0 \\
30 \\
0 \\
40\end{array}$ & $\begin{array}{r}156 \\
150 \\
143 \\
139 \\
= \\
128 \\
124 \\
114 \\
120 \\
108 \\
106\end{array}$ & $\begin{array}{r}192 \\
192 \\
192 \\
265 \\
\overline{174} \\
180 \\
168 \\
174 \\
180 \\
180\end{array}$ & $\begin{array}{l}104 \\
138 \\
123 \\
134 \\
116 \\
140 \\
121 \\
146 \\
115 \\
143 \\
137 \\
154\end{array}$ & $\begin{array}{l}136 \\
182 \\
158 \\
195 \\
147 \\
169 \\
131 \\
165 \\
124 \\
148 \\
120 \\
137\end{array}$ & $\begin{array}{l}= \\
= \\
= \\
= \\
=\end{array}$ & $\begin{array}{r}232 \\
252 \\
236 \\
232 \\
= \\
\overline{=} \\
224 \\
160 \\
=\end{array}$ & $\begin{array}{l}164 \\
164 \\
164 \\
168 \\
164 \\
164 \\
160 \\
172 \\
168 \\
164 \\
160 \\
166\end{array}$ & $\begin{array}{l}200 \\
228 \\
208 \\
228 \\
200 \\
210 \\
196 \\
196 \\
204 \\
168 \\
184 \\
144\end{array}$ & $\begin{array}{l}163 \\
172 \\
127 \\
152 \\
140 \\
161 \\
144 \\
157 \\
138 \\
170 \\
146 \\
174\end{array}$ & $\begin{array}{l}246 \\
258 \\
234 \\
234 \\
246 \\
228 \\
255 \\
222 \\
228 \\
201 \\
240 \\
168\end{array}$ & $\begin{array}{l}222 \\
240 \\
228 \\
252 \\
234 \\
192 \\
234 \\
252 \\
240 \\
276 \\
237 \\
258\end{array}$ & $\begin{array}{l}268 \\
276 \\
274 \\
260 \\
268 \\
236 \\
268 \\
212 \\
276 \\
200 \\
272 \\
160\end{array}$ \\
\hline
\end{tabular}




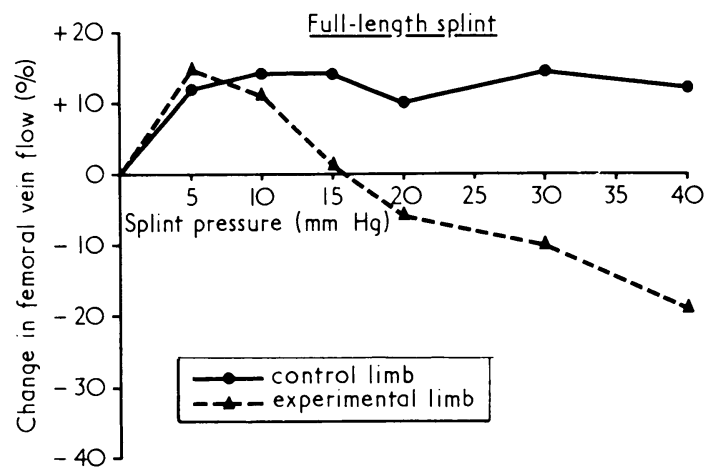

FIG. 6-Changes in human femoral venous blood flow produced by varying splint pressures for full-length leg and thigh splint.

\section{Discussion}

The effects of external compression of the leg of horizontal supine subjects on the velocity of blood flow has been assessed by many workers and proved to produce a definite increase in the velocity of both intravenously injected dyes (Stanton et al., 1949) and radioactive isotopes (Osborn and Wright, 1949; Meyrowitz and Crook, 1960; Meyrowitz and Nelson, 1964). Ochsner (1946) suggested that compression of the calf would divert superficial venous blood into deep channels and thus accelerate the flow in the deep veins of the calf. However, Stanton et al. (1949), using phlebography, showed that the application of a pressure of $20-35 \mathrm{~mm} \mathrm{Hg}$ did not divert the flow from the superficial into the deep veins, but increased the velocity of the venous flow in both the superficial and deep veins. Meyrowitz and Nelson (1964) using ${ }^{121}$ I-orthoiodohippuric acid, found that application of an external pressure of $10 \mathrm{~mm} \mathrm{Hg}$ increases the velocity of venous flow in the long saphenous vein by an average of $81 \%$. They also found that wearing compression stockings prevented a bolus of radioactive isotope from being trapped in the venous sinuses of the calf. This important finding may indicate that compression of the calf at a pressure of $10 \mathrm{~mm} \mathrm{Hg}$ produces complete collapse of the thin-walled soleal venous sinuses. Collapse of the soleal sinuses by compression of the calf was demonstrated by Clark et al. (1965), who showed radiographically that externally applied pressure increased the velocity of the venous blood but did not result in any filling of the soleal venous system.

Trials based on clinical diagnosis of deep vein thrombosis have shown that its incidence was significantly decreased when patients wore elastic stockings (Wilkins et al., 1952; Wilkins and Stanton, 1953; Makin, 1969). The diagnosis of thrombosis in these trials was based on clinical signs which are now known to be inaccurate. Clinical signs can be found only in half of the patients affected by deep vein thrombosis, despite the most careful examination of the legs (Flanc et al., 1968; Browse and Negus, 1970). The net compression pressure applied to the calf was accurately measured only by Makin et al. (1969), who found that the net pressure exerted by Tubigrip on the calf had a mean value of $13.82 \mathrm{~mm} \mathrm{Hg}$.

Halperin et al. (1948) used thermometric, blood gasometric, and plethysmographic methods to investigate the effects of external application of pressure on the perfusion of the limb. They reported that the external application of a pressure of $10 \mathrm{~mm} \mathrm{Hg}$ was enough to reduce the circulation in normal limbs. They attributed the resultant diminution of arterial inflow and venous outflow to two possible factors: first, a reduction of arteriovenous pressure gradients, and, secondly, a decrease in the calibre of small vessels in the compressed area caused an increase in resistance to flow.

The results of the present investigation agree substantially with those of Halperin et al. (1948), and support their hypo- thetical suggestions. It is evident from Fig. 3 that a compression pressure exceeding $5 \mathrm{~mm} \mathrm{Hg}$ produces a progressive diminution of the femoral arterial blood flow. Also Fig. 4 clearly shows that a compression pressure of $10 \mathrm{~mm} \mathrm{Hg}$ significantly reduces the vascular conductance. The vascular conductance measurement is a very sensitive indication of the vascular tone, being the inverse of the peripheral resistance. Therefore, it can be seen from this investigation (Table II) for the first time that there exist a numerical relationship between limb compression at pressures exceeding $5 \mathrm{~mm} \mathrm{Hg}$ and the resultant increase in peripheral resistance.

A higher compression pressure is required before any significant diminution of the femoral venous blood flow can be seen. Compression pressure exceeding $12 \mathrm{~mm} \mathrm{Hg}$ produced a progressive decrease in the femoral venous flow. However, sustained application of external pressure of the magnitude of even $5 \mathrm{~mm} \mathrm{Hg}$ produced an initial rise, which lasted 10-15 minutes and then gradually decreased (Fig. 4). It would seem that for maximal effect on venous flow the external pressure should approximately equal intravascular pressure. This would imply that while our results hold for subjects in the resting recumbent state they would not apply to ambulant patients.

The findings from this investigation may provide an explanation for the underlying causes of failure of compression of the leg to prevent deep vein thrombosis (Flanc et al., 1969; Rosengarten et al., 1970). Both Flanc and Rosengarten and their associates conducted trials to evaluate the efficacy of compression stockings in the prophylaxis of deep venous thrombosis in surgical patients. They used the very sensitive ${ }^{125} \mathrm{I}$-fibrinogen technique for the diagnosis of deep vein thrombosis. The results of these two trials were in conflict with those of Wilkins et al. (1952), Wilkins and Stanton (1953), and Makin (1969), and showed that compression stockings failed to produce any significant reduction in the incidence of deep vein thrombosis.

Makin et al. (1969) showed that the mean pressure exerted by the Tubigrip was $13.82 \mathrm{~mm} \mathrm{Hg}$ and resulted in more than doubling of the mean velocity of the venous flow. Our investigation, however, has shown clearly that a compression pressure of $13.82 \mathrm{~mm} \mathrm{Hg}$ applied to the calf of a supine subject will significantly reduce the femoral venous volume flowrate (Fig. 1). The difference between the results obtained by Makin et al. (1969) and those obtained in this investigation illustrates clearly the differences between velocity and volume flowrate measurements. Halperin et al. (1948) showed that despite the diminution in venous flow with external applied pressure it remarkably increased the linear velocity. They suggested, therefore, that this increase in velocity was due to a disproportionately greater decrease in cross-sectional area of the venous bed.

The findings of the present investigation support those of Burton and Yamada (1951), Yamada (1954), Roddie and Shepherd (1957), Gaskell and Krisman (1958), Coles and Gough (1960), Ashton (1962a, 1962b), and Jennings (1964), Ashton (1966), Ginsberg et al. (1967), and Campion et al. (1968), who showed that external application of pressure may drastically impair the perfusion of the limb. Our findings, however, were in conflict with those of Gardner (1966), Spooner et al. (1967), and Welply (1967). Ashton (1966) showed that release of splint pressure was followed by reactive hyperaemia in all her subjects. We confirmed these findings in one patient who was bandaged with a double layer of Tubigrip in a similar fashion to that described by Makin et al. (1969). Flow was measured in the femoral vein with a cuff electromagnetic flow probe. On removal of the elastic stocking a pronounced hyperaemic effect was noted.

In conclusion, it has been shown that low external pressures such as can be achieved by crepe (Spiro et al., 1970) or Tubigrip bandaging (Makin et al., 1969) have only a slight effect on femoral blood flow in recumbent anaesthetized patients. It would seem reasonable to assume that in ambulant patients the haemodynamic effects would be insignificant unless some grading of the applied pressure (Wood, 1968) were possible. 
Requests for reprints should be sent to Dr. V. C. Roberts.

\section{References}

Ashton, H. (1962a). Clinical Science, 22, 79.

Ashton, H. (1962b). Clinical Science, 22, 89

Ashton, H. (1966). British Medical fournal, 2, 1427.

Browse, N. L., and Negus, D. (1970). British Medical fournal, 3, 615.

Burton, A. C., and Yamada, S. (1951). Fournal of Applied Physiology, 164, 319.

Campion, E. C., Hoffman, D. C., and Jepson, R. P. (1968). Australia and New Zealand fournal of Surgery, 38, 154.

Clark, C., and Cotton, L. T. (1968). British Fournal of Surgery, 55, 211 Clark, C., Cotton, L. T., and Zarek, J. M. (1965). In Biomechanics and Related Bioengineering Topics, ed. R. M. Kenedi. Oxford, Pergamon Press.

Coles, D. R., and Gough, K. R. (1960). Clinical Science, 19, 587.

Cotton, L. T., and Clark, C. (1965). Annals of the Royal College of Surgeons of England, 36, 214.

Dyde, J. A., and Bethel, A. N. (1968). British fournal of Surgery, 55, 917.

Flanc, C., Kakkar, V. V., and Clark, M. B. (1968). British fournal of Surgery, $55,742$.

Flanc, C., Kakkar, V. V., and Clark, M. B. (1969). Lancet, 1, 477.

Foote, R. R. (1960). Varicose Veins, 3rd ed. London, Butterworths.

Gardner, W. J. (1966). Fournal of the American Medical Association, 196, 491

Gardner, W. J. (1966). Fournal of the American Medical Association, 196,

Gaskell, P., and Krisman, A. M. (1958). Circulation Research

Ginsberg, M., Miller, J. M., and McElfatrick, G. C. (1967). Fournal of the American Medical Association, 200, 180.
Hadfield, G. (1950). Annals of the Royal College of Surgeons of England, 6, 219. Halperin, M. H., Friedland, C. K., and Wilkins, R. W. (1948). American Heart fournal, 35, 221.

Jennings, A. M. C. (1964). British fournal of Anaesthesia, 36, 683.

McLachlin, A. D., McLachlin, J. A., Jory, T. A., and Rawlings, E. G. (1960). Annals of Surgery, 152, 678.

Makin, G. S. (1969). British fournal of Surgery, 56, 373.

Makin, G. S., Mayes, F. B., and Holroyd, A. M. (1969). British fournal of Surgery, 56, 369.

Meyrowitz, B. R., and Crook, A. (1960). Lancet, 2, 122.

Meyrowitz, B. R., and Nelson, R. (1964). Surgery, 56, 481

Ochsner, A. (1946). Fournal of the American Medical Association, 132, 827.

Osborn, S. B., and Wright, H. P. (1949). British fournal of Radiology, 22, 110

Roberts, V. C. (1971). Lancet, 1, 136.

Roberts, V. C., Sabri, S., and Cotton, L. T. (1971). In press.

Roddie, I. C., and Shepherd, J. T. (1957). Fournal of Physiology, 136, 498 Rosengarten, D. S., Laird, J., Jeyasingh, K., and Martin, P. (1970). British fournal of Surgery, 57, 296.

Spiro, M., Roberts, V. C., and Richards, J. B. (1970). British Medical Fournal, 1, 719 .

Spooner, J. B., Corne, S. J., and Stephens, R. J. (1967). British Medical fournal, 1, 297.

Stanton, J. R., Freis, E. D., and Wilkins, R. W. (1949). Fournal of Clinical Investigation, 28, 553.

Tamada, S. (1954). Fournal of Applied Physiology, 6, 495

Welply, W. R. (1967). British Medical fournal, 1, 297.

Wilkins, R. W., Mixter, G., Stanton, J. R., and Littler, J. (1952). New England fournal of Medicine, 246, 360 .

Wilkins, R. W., and Stanton, J. R. (1953). New England fournal of Medicine, 248,1087

Wood, J. E. (1968). Scientific American, 218, 86.

\title{
Intrathecal Chemotherapy in Burkitt's Lymphoma*
}

\author{
J. L. ZIEGLER, A. Z. BLUMING
}

British Medical fournal, 1971, 3, 508-512

\section{Summary}

Meningeal involvement with Burkitt lymphoma cells constitutes the most challenging therapeutic problem in the management of Burkitt's tumour. The results of intrathecal chemotherapy with methotrexate or cytosine arabinoside in 55 episodes of malignant pleocytosis in 38 patients with Burkitt's tumour are described. The response was complete in nearly all patients after the administration of either agent. Cerebrospinal fluid (C.S.F.) remissions were more prolonged in patients receiving intrathecal methotrexate or cytosine arabinoside daily for four days as opposed to a 10-day schedule. $A$ controlled randomized trial of "prophylactic" intrathecal chemotherapy in patients without malignant cells in the C.S.F. on admission showed no protective effect against the subsequent development of malignant pleocytosis. Future therapeutic approaches are considered in the light of these results.

\section{Introduction}

In a previous communication from this centre (Ziegler et al., 1970a) the neurological features of Burkitt's lymphoma were

* Supported by Contract No. PH 43-67-1343 from the National Cancer Institute, N.I H., Bethesda, Maryland, U.S.A.

\section{Makerere University Medical School, Kampala, Uganda}

J. L. ZIEGLER, M.D., Director, Uganda Cancer Institute (Senior Investigator, Medicine Branch, National Cancer Institute, Bethesda, Maryland, U.S.A.)

A. Z. BLUMING, M.D., Director, Lymphoma Treatment Centre (Senior Investigator, Medicine Branch, National Cancer Institute, Bethesda, Maryland, U.S.A.) described. The presence of Burkitt lymphoma cells in the cerebrospinal fluid (malignant pleocytosis) was a prominent finding, and though patients with this complication were initially responsive to intrathecal chemotherapy, relapse was common and the prognosis was poor. In a neoplasm characterized by dramatic and often durable remissions following chemotherapy the successful management of malignant pleocytosis presents a major therapeutic challenge (Clifford et al., 1967; Ziegler et al., 1970a). We have now treated 55 episodes of malignant pleocytosis in 38 patients with Burkitt's lymphoma utilizing methotrexate and cytosine arabinoside in seven different intrathecal regimens. This report summarizes the results of intrathecal chemotherapy in this group of patients, some of whom have been followed for up to three years. In addition, prophylactic intrathecal chemotherapy was evaluated in a randomized study in 20 patients with Burkitt's lymphoma presenting without malignant pleocytosis.

\section{Patients and Methods}

All patients admitted to the Lymphoma Treatment Centre, an 18-bed research ward affiliated with Makerere University Medical School, were referred from Mulago Hospital, Kampala, or from up-country district hospitals in Uganda. On arrival at the centre the patients underwent a careful clinical evaluation which included a complete neurological examination and lumbar puncture. The cerebrospinal fluid (C.S.F.) cytology was examined on admission and at least at monthly intervals, several methods (Steel et al., 1965; Ziegler et al., 1970a) being used to detect the presence of malignant cells. The patients were clinically staged according to criteria previously outlined (Ziegler et al., 1970b); these are summarized in Table I.

Previous to August 1969 systemic treatment consisted of intravenous cyclophosphamide, $40 \mathrm{mg} / \mathrm{kg}$, given in one-dose or six-dose schedules (multiple doses given at intervals of two to three weeks) to randomly selected patients who had a complete response following the first dose (Ziegler et al., 1970b). After 